\title{
Movimento da negritude: uma breve reconstrução histórica
}

\author{
Petrônio Domingues ${ }^{1}$
}

\begin{abstract}
Cabe mais uma vez insistir: não nos interessa a proposta de uma adaptação aos moldes da sociedade capitalista e de classes. Esta não é a solução que devemos aceitar como se fora mandamento inelutável. Confiamos na idoneidade mental do negro e acreditamos na reinvenção de nós mesmos e de nossa história. Reinvenção de um caminho afro-brasileiro de vida, fundado em sua experiência histórica, na utilização do conhecimento crítico e inventivo de suas instituições golpeadas pelo colonialismo e pelo racismo. Enfim reconstruir no presente uma sociedade dirigida ao futuro, mas levando em conta o que ainda for útil e positivo no acervo do passado.
\end{abstract}

Abdias do Nascimento

\section{Resumo}

O objetivo deste artigo é reconstruir em concisos apontamentos, a história do movimento da negritude, apresentando alguns de seus dilemas, contradições e reflexo no interior do movimento negro internacional na luta pela libertação dos povos africanos e da diáspora. Por último abordaremos como esse movimento foi introduzido no Brasil.

Palavras-chave: negritude, negro, relações raciais, racismo.

\begin{abstract}
The purpose of the present is reconstructing, in brief appointments, the history of blackness, presenting some of its dilemmas, contradictions and reflexes in the bosom of the international black people movement in the struggle for African black people liberty and its diáspora. Finally, we will approach how this movement has been introduced in Brazil.
\end{abstract}

Key-words: blackness, black people, racial relationships, racism.

\section{Introdução ${ }^{2}$}

O termo negritude vem adquirindo diversos "usos e sentidos" nos últimos anos. Com a maior visibilidade da "questão étnica" no plano internacional e do movimento de afirmação racial no Brasil, negritude passou a ser um conceito dinâmico, o qual tem um

\footnotetext{
${ }^{1}$ Professor de História da Universidade Estadual do Oeste do Paraná (Unioeste), Doutorando do Programa de História Social-USP e autor do livro Uma história não contada. Negro, racismo e branqueamento em São Paulo no pós-abolição. São Paulo: Ed. Senac, 2004.

${ }^{2}$ Agradeço ao Marcos Cesaretti, pela leitura, sugestões e correções.

Mediações - Revista de Ciências Sociais, Londrina, v. 10, n.1, p. 25-40, jan.-jun. 2005 MOVIMENTO DA NEGRITUDE: UMA BREVE RECONSTRUÇÃO HISTÓRICA

Petrônio Domingues
} 
caráter político, ideológico e cultural. No terreno político, negritude serve de subsídio para a ação do movimento negro organizado. No campo ideológico, negritude pode ser entendida como processo de aquisição de uma consciência racial. Já na esfera cultural, negritude é a tendência de valorização de toda manifestação cultural de matriz africana. Portanto, negritude é um conceito multifacetado, que precisa ser compreendido a luz dos diversos contextos históricos. Neste artigo pretendemos traçar uma breve reconstrução histórica do movimento da negritude, apresentando alguns de seus dilemas, seu reflexo no interior do movimento negro internacional e de que maneira foi introduzido no Brasil.

Nosso principal argumento é sustentar que o movimento da negritude, na fase inicial, cumpriu um papel revolucionário, rompendo com os valores da cultura eurocêntrica. No entanto, na medida em que se ampliou e adquiriu uma conotação mais política, diluiu seu potencial transformador. O movimento passou a padecer de uma série de contradições insolúveis, a ponto de alguns de seus principais dirigentes defenderem posições políticas conservadoras.

\section{O movimento da negritude nasce fora da África}

O movimento da negritude foi idealizado fora da África. Ele provavelmente surgiu nos Estados Unidos, passou pelas Antilhas; em seguida atingiu a Europa, chegando a França aonde adquiriu corpo e foi sistematizado. Depois, o movimento expandiu-se por toda a África negra e as Américas (inclusive o Brasil), tendo sua mensagem, assim, alcançado os negros da diáspora.

O afro-americano W. E. B. Du Bois (1868-1963) é considerado o patrono do panafricanismo, movimento político e cultural que lutava tanto pela independência dos países africanos do jugo colonial quanto pela construção da unidade africana. Pelo fato de Du Bois ser uma das primeiras lideranças a adotar com veemência um discurso de orgulho racial e de volta às origens negras é considerado da mesma maneira, o pai simbólico do movimento de tomada de consciência de ser negro, embora o termo negritude tenha sido cunhado somente anos mais tarde. Du Bois exerceu forte ascendência sobre os escritores negros 
estadunidenses. Seu livro Almas Negras "tornou-se verdadeira bíblia para os intelectuais do movimento Renascimento Negro". ${ }^{3}$

Por volta de 1920 surgiu no bairro negro de Nova Iorque, o Harlem, nos Estados Unidos, um movimento literário e artístico denominado New Negro (ou "Negro Renaissance"), cuja proposta cultural era "exorcizar" os estereótipos e preconceitos disseminados contra o negro no imaginário social. Ao contrário de lamentarem-se pela sua condição racial, os ativistas do movimento enalteciam a cor do povo negro em suas obras. Dentre os escritores que se destacaram, os que mais adquiriram notoriedade foram Langston Hughes, Claude Mackay e Richard Wright. Já nas ilhas do Caribe, e em particular em Cuba, foi articulado o movimento denominado negrismo cubano, tendo como principal expoente o poeta negro Nicolás Guillén. No Haiti, Jean Price-Mars fomentou em conjunto com outros intelectuais, o movimento indigenista de reabilitação da herança cultural africana, valorizando as línguas crioulas e a religião vodu. Contrário a ocupação norteamericana na ilha, esse líder negro encampou a resistência anticolonial e promoveu um trabalho de conscientização sobre a história africana. Segundo Nascimento, Price-Mars, "precursor e mestre da liderança negra independentista da luta nacional africana contribuiu muito para a formação do importante movimento da negritude". ${ }^{4}$ Aimé Césaire vai mais longe, preconizando que "o Haiti foi o país em que a negritude se ergueu pela primeira vez". 5

Em Paris, no período entre-guerras, um grupo de estudantes negros oriundos dos países colonizados (Antilhas e África) iniciou um processo de mobilização cultural. Quando esses estudantes começaram a freqüentar as universidades européias - sobretudo as de Paris e Londres - constatou que a civilização ocidental não era um modelo universal e absoluto tal como era ensinado na colônia. Nesse contexto, despertou-se uma consciência racial, e, por conseguinte, a disposição de lutar a favor do resgate da identidade cultural esvaecida do povo negro.

Em junho de 1932, alguns estudantes negros antilhanos publicaram uma revista, a Légitime Défense (Legítima Defesa), tendo editado só um número. O tom é de um manifesto. Nessa revista denunciavam a opressão racial e a política de dominação cultural

\footnotetext{
${ }^{3}$ Munanga, Kabengele. Negritude; usos e sentidos. 2 edição. São Paulo: Ática, 1988. p. 37.

${ }^{4}$ Nascimento, Elisa Larkim. Pan-africanismo na América do Sul. Petrópolis: Vozes, 1981. p. 102.

${ }^{5}$ Bernd, Zilá. A questão da negritude. São Paulo: Brasiliense, 1984. p. 30. 
colonialista. O alvo do ataque também era "o mundo capitalista, cristão e burguês". ${ }^{6}$ Os jovens escritores defendiam que o intelectual devia assumir sua origem racial. Além disso, apregoavam a libertação do estilo, da forma e da imaginação frente aos modelos literários franceses.

Dois anos depois em 1934, os estudantes negros em Paris lançam a revista L'étudiant Noir (o Estudante Negro). Léon Damas proclamava: "não somos mais estudantes martinicanos, senegaleses ou malgaches, somos cada um de nós e todos nós, um estudante negro". Daí o título da revista. Contrapondo-se a política assimilacionista das potências européias retomaram a bandeira a favor da liberdade criadora do negro e condenaram o modelo cultural ocidental. Como instrumentos ideológicos de libertação, advogavam o comunismo, o surrealismo e a volta às raízes africanas. A revista teve importância fundamental na difusão do movimento. Organizando reuniões, exposições, assembléias, publicando artigos e poemas em outras revistas, esse grupo conseguiu progressivamente transmitir uma imagem positiva da civilização africana. Deste período adquiriram notoriedade os três diretores da revista: Aimé Césaire (Martinica) - que foi o criador da palavra negritude - Léon Damas (Guiana Francesa) e Léopold Sédar Senghor (Senegal).

Esse movimento literário a favor da personalidade negra e de denúncia contundente da dominação cultural e da opressão do capitalismo colonialista marcou a fundação da ideologia da negritude no cenário mundial.

\section{O significado do termo negritude}

A palavra négritude em francês deriva de nègre, termo que no início do século $\mathrm{XX}$ tinha um caráter pejorativo, utilizado normalmente para ofender ou desqualificar o negro, em contraposição a noir, outra palavra para designar negro, mas que tinha um sentido respeitoso. A intenção do movimento foi justamente inverter o sentido da palavra négritude ao pólo oposto, impingindo-lhe uma conotação positiva de afirmação e orgulho racial. ${ }^{7}$

\footnotetext{
${ }^{6}$ Damato, Diva. "Negritude, negritudes". Revista Através, n ${ }^{\circ}$ 1, São Paulo, 1983. p. 118.

${ }^{7}$ Em entrevista, Aimé Césaire explica como surgiu o termo negritude: "Como los antilhanos se avergonzaban de ser negros, buscaban toda classe de perífrasis para designar a un negro. Se hablaba de hombre de piel

Mediações - Revista de Ciências Sociais, Londrina, v. 10, n.1, p. 25-40, jan.-jun. 2005 MOVIMENTO DA NEGRITUDE: UMA BREVE RECONSTRUÇÃO HISTÓRICA

Petrônio Domingues
} 
Nessa perspectiva, a tática foi de desmobilizar o inimigo em um de seus principais instrumentos de dominação racial: a linguagem. O próprio Aimé Césaire assinalava que o movimento da negritude representou uma revolução na linguagem e na literatura.

O termo negritude apareceu com esse nome, pela primeira vez, em 1939, no poema Cahier d'un Retour au Pays Natal ("Caderno de um regresso ao país natal"), escrito pelo antilhano Césaire e editado por Volontés:

Minha negritude não é nem torre nem catedral

Ela mergulha na carne rubra do solo

Ela mergulha na ardente carne do céu

Ela rompe a prostração opaca de sua justa paciência.

Na sua fase inicial, o movimento da negritude tinha um caráter cultural. A proposta era negar a política de assimilação à cultura (conjunto dos padrões de comportamento, das crenças, das instituições e dos valores transmitidos coletivamente) européia. O dilema para os africanos e negros da diáspora, assevera Franz Fanon, deixou de ser "embranquecer ou desaparecer". ${ }^{8}$ Até essa época considerava-se positivo apenas, os modelos culturais brancos que vinham da Europa. Para rejeitar esse processo de alienação, os protagonistas da ideologia da negritude passaram a resgatar e a enaltecer os valores e símbolos culturais de matriz africana. Como salienta Jean Paul Sartre, "trata-se de morrer para a cultura branca a fim de renascer para a alma negra".

Hodierno, negritude é um termo polissêmico. Segundo a classificação de Zilá Bernd, ele pode significar o fato de se pertencer à raça negra; à própria raça como coletividade; à consciência e à reivindicação do homem negro civilizado; à característica de

curtida`y otras estupideces por el estilo... y entonces adoptamos la palabra nègre como palabra-desafío. Era éste um nombre de desafío. Era un poco de reacción de joven en cólera. Ya que se avergonzaban de la palabra nègre, pues bien, nosotros emplearíamos nègre. Debo decir que cuando fundamos L'Étudiant noir yo quería em realidad llamarlo L`Étudiant nègre, pero hubo gran resistencia en los medios antilhanos... Algunos consideraban que la palabra nègre resultaba demasiado ofensiva: por ello me tomé la libertad de hablar de negritud (négritude). Havía en nosotros una voluntad de desafío, una violenta afirmación en la palabra nègre y em la palavra négritude". Depestre, René. "Saludo y despedida a la negritud". In: Fraginals, Manuel Moreno (org.). África em América Latina. México: Ed. Siglo XXI/Unesco, 1977. p. 337.

${ }^{8}$ Fanon, Frantz. Pele negra, máscaras brancas. Trad. Alexandre Pomar. Porto: Paisagem, s/d. p. 131.

${ }^{9}$ Sartre, Jean-Paul. Reflexões sobre o racismo. Trad. J. Guinsburg. $5^{a}$ edição. São Paulo: Difel, 1968. p. 104. 
um estilo artístico ou literário; ao conjunto de valores da civilização africana. ${ }^{10}$ Já o Novo Aurélio define negritude como: 1) estado ou condição das pessoas da raça negra; 2) ideologia característica da fase de conscientização pelos povos negros africanos da opressão colonialista, a qual busca reencontrar a subjetividade negra observada objetivamente na fase pré-colonial e perdida pela dominação da cultura ocidental. E, finalmente, o Dicionário Houaiss da Língua Portuguesa, o qual define negritude como sinônimo de 1) qualidade ou condição de negro; 2) sentimento de orgulho racial e conscientização do valor e riqueza cultural dos negros.

\section{Os arautos da negritude}

Na concepção de Aimé Césaire, negritude é simplesmente o ato de assumir ser negro e ser consciente de uma identidade, história e cultura específica. Césaire definiu a negritude em três aspectos: identidade, fidelidade e solidariedade. A identidade consiste em ter orgulho da condição racial, expressando-se, por exemplo, na atitude de proferir com altivez: sou negro! A fidelidade é a relação de vínculo indelével com a terra-mãe, com a herança ancestral africana. A solidariedade é o sentimento que une, involuntariamente, todos os "irmãos de cor" do mundo; é o sentimento de solidariedade e de preservação de uma identidade comum. ${ }^{11}$

Já para outro expoente do movimento da negritude, o poeta senegalês Léopold Sédar Senghor, existe uma "alma negra" inerente à estrutura psicológica do africano. A "alma negra" teria uma natureza emotiva em detrimento à racionalidade do branco. Trata-se de um conceito de negritude essencialista em que "a emoção é negra como a razão é grega". Enquanto a civilização européia seria fundamentalmente materialista, os valores negroafricanos estariam fundados na vida, na emoção e no amor. Para Senghor, estes atributos constituíam um privilégio do negro. O perigo dessa acepção é que reforça o preconceito, segundo o qual a raça negra é incapaz de atingir certos níveis de inteligência e de promover autonomamente o desenvolvimento de uma nação, ou seja, a raça negra seria incapaz de

\footnotetext{
${ }^{10}$ Bernd, Zilá. O que é Negritude. São Paulo: Brasiliense, 1988. p. 16.

${ }^{11}$ Munanga, K. Negritude..., op. cit., p. 44.

Mediações - Revista de Ciências Sociais, Londrina, v. 10, n.1, p. 25-40, jan.-jun. 2005 MOVIMENTO DA NEGRITUDE: UMA BREVE RECONSTRUÇÃO HISTÓRICA

Petrônio Domingues
} 
alcançar determinado estágio do conhecimento científico e tecnológico, posto que sua natureza fosse, essencialmente, munida de valores espirituais.

\section{Negritude: instrumento de libertação política}

Com uma arrojada proposta de ruptura, o movimento da negritude pelo menos na sua fase inicial recebeu a proeminente influência ideológica do marxismo. Isto é, o marxismo constituiu instrumental teórico fundamental no despertar da necessidade de uma consciência negra crítica e autônoma. Por exemplo, os notáveis poetas negros Langston Hughes e Richard Wright dos Estados Unidos, Jacques Roumain e Brière do Haiti, Nicolas Guillen de Cuba e o próprio Aimé Césaire da Martinica eram membros orgânicos do Partido Comunista. Entretanto, na medida em que o movimento expandiu sua inserção social e poder de mobilização operou-se uma divergência sob o papel do marxismo: de um lado, um grupo minoritário passou a associar negritude à luta de todos oprimidos da sociedade, independente da cor da pele e de outro, um grupo majoritário continuou defendendo que o movimento da negritude pretendia, exclusivamente, construir uma consciência racial sem vínculo com a luta dos demais grupos oprimidos do sistema capitalista.

Com o tempo, o objetivo do movimento se ampliou. Além da construção da personalidade ou consciência negra, seus adeptos também passaram a protestar contra a ordem colonial e a lutar pela emancipação política dos povos africanos. Assim, depois da segunda Guerra Mundial (1939-1945), o movimento da negritude entrou em uma nova fase, que podemos qualificar de militante. $\mathrm{O}$ mais importante, naquele instante, era colocar a ideologia da negritude a serviço da causa política maior: a libertação das colônias africanas do jugo europeu. Ultrapassando os marcos da literatura, a negritude encampa a luta pela conquista do poder, pela independência e assume, igualmente, um discurso de repudio ao imperialismo e ao racismo. A criação poética adquire um caráter político. Nessa fase, o movimento impulsionou ideologicamente a luta das organizações políticas e dos sindicatos africanos. O auge desse processo foi na década de 1960, quando o movimento se 
internacionalizou, alcançando adeptos, inclusive nos países do denominado Terceiro Mundo como o Brasil.

Após a conquista da soberania dos países africanos, o movimento da negritude continuou sendo o principal instrumento ideológico na causa da unidade africana e dos projetos políticos de diversos países africanos.

\section{A natureza pequeno-burguesa da negritude}

Quando ganhou força na França, a negritude era a ideologia de uma elite negra letrada, na medida em que congregava os estudantes oriundos de famílias "remediadas" dos países colonizados (Antilhas e África). O discurso de volta às origens, alardeado pela ideologia da negritude não atingia as massas africanas, as quais permaneciam em sua maioria analfabetas e preservando os valores da cultura tradicional. Por isso, o discurso da negritude na África, a princípio, apenas sensibilizava a elite colonial negra, que vivia material e espiritualmente nos moldes do colonizador.

No transcurso da colonização, surgiu uma pequena-burguesia negra: camada social de africanos constituída de funcionários da colônia, trabalhadores especializados em diversos ramos da indústria, empregados do comércio, profissionais liberais e um número ainda que diminuto - de proprietários urbanos e rurais. A elite negra situava-se socialmente entre as massas trabalhadoras africana e a minoria de brancos, representantes da metrópole. Apesar do contato com as massas camponesas e culturas tradicionais africanas, aquela pequena-burguesia negra aspirava ter um nível de vida equivalente ao dos brancos. Para tanto incorporavam os hábitos, roupas, língua e arquitetura do colonizador. ${ }^{12}$ As negras em alguns casos alisavam os cabelos e buscavam clarear a pele.

Porém, os negros da África e da diáspora que haviam assimilado o branqueamento, não conseguiam fugir do drama da marginalização. Vestidos a moda européia "de terno, óculos, relógio e caneta no bolso do paletó, fazendo um esforço enorme para pronunciar adequadamente as línguas metropolitanas", ${ }^{13}$ não deixavam de ser discriminados. No plano social, continuavam sendo negros e, conseqüentemente, tratados como inferiores.

\footnotetext{
${ }^{12}$ A este respeito, ver Memmi, Albert. Retrato do colonizado precedido pelo retrato do colonizador. Trad. Roland Corbisier e Mariza Pinto Coelho. $3^{\text {a }}$ edição. Rio de Janeiro: Paz e Terra, 1989.

${ }^{13}$ Munanga, K. Negritude..., op. cit., p. 30. 
Chegando a Europa, as lojas, hotéis, teatros, cinemas e restaurantes não lhes abriam as portas. Nas ruas eram objetos de insultos raciais e vítimas de todo tipo de humilhação. "Ao seu esforço em vencer o desprezo, em vestir-se como o colonizador, em falar a sua língua e comportar-se como ele, o colonizador opõe a zombaria". ${ }^{14}$ Os sacrifícios do negro eram ridicularizados. Como diz Fanon "o evoluído de repente se descobre rejeitado por uma civilização que ele no entanto assimilou". ${ }^{15}$

E foi justamente para dar uma resposta a esse sentimento de marginalização racial e frustração existencial que a pequena-burguesia negra resolveu revalorizar sua identidade no "mundo dos brancos", empreendendo um discurso de afirmação racial e volta às raízes da cultura africana. Preterida socialmente na Europa, a pequena-burguesia intelectual negra encontra como saída a negação do embranquecimento de seus "corpos e mentes"; a aceitação simbólica de sua herança étnica, a qual deixaria de ser considerada inferior. Negritude, nesse sentido, tratou-se de uma reação à branquitude reinante da cultura ocidental.

\section{O orfeu negro}

O filósofo francês Jean-Paul Sartre, no seu famoso texto Orfeu Negro de 1948, foi um dos primeiros intelectuais de proa a fazer uma reflexão aprofundada do movimento da negritude. Orfeu Negro foi escrito como introdução a uma antologia de poesia negra, organizada por Leopold Senghor. No texto, Sartre reconhecia o papel subversivo do movimento da negritude em determinado momento histórico: seja porque negava os valores culturais do opressor branco, seja porque despertava no negro, altivez e orgulho racial. A negritude seria uma reação do negro à supremacia branca, cuja proeza era apontar para uma progressão dialética nas relações raciais. Segundo Sartre, o racismo do branco seria a tese, a negritude sua antítese, um princípio transitório fundado no racismo anti-racista: "A unidade final, que aproximará todos os oprimidos no mesmo combate, deve ser precedida nas colônias, por isso que eu chamaria momento da separação ou da negatividade: este racismo anti-racista é o único caminho capaz de levar à abolição das diferenças de raça". ${ }^{16}$

\footnotetext{
${ }^{14}$ Idem, ibidem.

${ }^{15}$ Fanon, F. Pele negra..., op. cit., p. 124.

${ }^{16}$ Sartre, J. P. Reflexões sobre..., op. cit., p. 94. 
O quadro de conflitos proveniente de um lado do racismo do branco e, de outro, do racismo de afirmação do negro, provocaria um salto qualitativo no padrão das relações raciais: denominado de síntese. Para Sartre, a síntese era a etapa seguinte, a própria superação da negritude: a construção de uma sociedade igualitária, sem nenhuma espécie de racismo. Na sua avaliação, a negritude era um instrumento ideológico progressista, que cumpria um papel reformista específico: colocar em cheque o status quo racial: "Mito doloroso e cheio de esperança, a Negritude, nascida do Mal e grávida de um Bem futuro, é viva qual uma mulher que nasce para morrer e sente a própria morte nos instantes mais ricos de sua vida; é repouso instável, fixidez explosiva, orgulho que renuncia a si próprio, absoluto que se sabe transitório". ${ }^{17}$

Nesse sentido, a negritude era entendida simplesmente como uma fase de transição: passagem e não término; jamais fim em si mesmo, mas apenas meio para construção de uma sociedade sem nenhuma forma de opressão racial, etapa cuja realização humana deixará de ser mediada pela cor da pele. Portanto, na perspectiva de Sartre, a negritude era uma espécie de mal necessário no processo emancipatório do conjunto dos oprimidos.

\section{Algumas contradições do movimento da negritude}

No decorrer dos anos, aflorou-se um dilema. Os adeptos do movimento da negritude certificaram-se que o passado nostálgico e glorioso da África, por si só, não resolveria as mazelas do presente. A necessidade de ação passou a ser um imperativo comum. Alguns ex-estudantes antilhanos tornaram-se administradores nas colônias africanas (como foi o caso de Paul Niger) ou optaram pela vida política, como foi o caso de Aimé Césaire, que se tornou deputado pela Martinica. Outros ex-estudantes africanos em Paris também optaram pelo ativismo político. Após a segunda Guerra Mundial, Senghor elegeu-se deputado pelo Senegal à Assembléia Nacional Francesa, Rabemananjara voltou para Madagascar e participou da revolta da ilha, N`Krumah dirigiu a luta pela libertação de Ghana, Apithy tornou-se ministro do Daomé e outros ainda fizeram carreira diplomática. ${ }^{18}$

\footnotetext{
${ }^{17}$ Idem, ibidem, p. 124.

${ }^{18}$ Damato, D. Negritude..., op., cit., p. 126.

Mediações - Revista de Ciências Sociais, Londrina, v. 10, n.1, p. 25-40, jan.-jun. 2005 MOVIMENTO DA NEGRITUDE: UMA BREVE RECONSTRUÇÃO HISTÓRICA

Petrônio Domingues
} 
Léopold Senghor, após a conquista da independência do Senegal em 1960, assumiu o poder desse país africano. Seu governo foi uma frustração geral, pois a ideologia da negritude foi totalmente capitulada à dominação das metrópoles capitalistas ocidentais de outrora. A defesa oficial dos "valores africanos" tornaram-se discursos vazios e reacionários no quadro de ausência de uma melhoria na qualidade de vida do povo senegalês e da continuação das estruturas sócio-econômicas marcadas pelas desigualdades. ${ }^{19}$ Senghor foi incapaz de entender que o principal inimigo a ser atacado, naquele instante, não era a "raça branca", mas as contradições de classe (a concentração de poder, renda e prestígio na mão de uma elite) de um lado, e o subdesenvolvimento econômico da África e suas conseqüentes mazelas sociais (o desemprego, analfabetismo, a fome e marginalização) de outro. Em nome de uma mística ideológica, a negritude, ele passou seus três mandatos subordinado aos interesses políticos das potências colonizadoras de antanho.

Uma outra contradição do movimento da negritude foi não rejeitar o uso da língua do colonizador. Senghor liderou um movimento de promoção e expansão na África da língua dos "deuses", o francês. Na sua concepção: "quando os filhos atingem a maioridade, constituem um novo lar e afrouxam os laços familiares, mas não os rompem. Somos em certo sentido, filhos espirituais da França". Ao adotar o francês como língua oficial, manteve-se o padrão cultural do "inimigo". Como as palavras são idéias, Sartre postula que "ao declarar em francês que rejeita a cultura francesa, o negro apanha com uma mão o que joga fora com a outra; instala em si mesmo como uma trituradora, o aparelho de pensar do inimigo". ${ }^{20}$ Esse é o mesmo entendimento de Fanon para quem "falar uma língua é assumir um mundo, uma cultura. O Antilhano que quer ser branco sê-lo-á tanto mais quanto tiver feito seu, o instrumento cultural que é a linguagem". ${ }^{21}$

\section{Negritude x marxismo}

A principal crítica do marxismo ortodoxo à ideologia da negritude reside no fato desta fazer apologia do conceito de raça em detrimento do conceito de classe. Para os

\footnotetext{
${ }^{19}$ Nascimento, E. L. Pan-africanismo..., op. cit., p. 222.

${ }^{20}$ Sartre, J. P. Reflexões sobre..., op. cit., p. 99.

${ }^{21}$ Fanon, F. Pele negra..., op. cit., p. 68. 
marxistas, raça é uma categoria particular que contempla exclusivamente um grupo específico, ao passo que classe é uma categoria universal, portanto mais abrangente e com maior potencial aglutinador. Uma acusação dos marxistas é que a ideologia da negritude ao privilegiar o discurso de afirmação racial, divide a luta dos oprimidos, quer desviando ou escamoteando o real problema do negro: sua situação de explorado do sistema capitalista. $\mathrm{O}$ discurso da negritude impediria, dessa maneira, a solidariedade entre todos os oprimidos, independente da cor da pele. No limite, a ideologia da negritude não seria um avanço, mas um atraso de consciência na luta pela emancipação dos oprimidos.

$\mathrm{Na}$ avaliação de Kabengele Munanga pode-se entender a visão marxista (ou classista) como uma tentativa de mascarar ideologicamente um mecanismo específico de opressão. ${ }^{22}$ Não se pode desconhecer que o mundo negro no seu conjunto vive uma situação específica, sofrendo discriminação baseada na cor. Aos problemas específicos devem corresponder dispositivos particulares. O primeiro passo do negro é assumir sua negritude. Ele sofre, é discriminado devido à cor de sua pele que os outros vêem, e não por causa da sua condição de classe. Antes do trabalhador africano e afrodescendente assumirem a bandeira do socialismo e do fim da exploração de classe é necessário que aprendam a pensar como negros:

O preto, como o trabalhador branco, é vítima da estrutura capitalista de nossa sociedade; tal situação desvenda-lhe a estreita solidariedade para além dos matizes de pele com certas classes de europeus oprimidos como ele; incita-o a projetar uma sociedade sem privilégio em que a pigmentação da pele será tomada como simples acidente. Mas, embora a opressão seja uma, ela se circunstancia segundo a história e as condições geográficas: o preto sofre o seu jugo, como preto, a título de nativo colonizado ou de africano deportado. E, posto que o oprima em sua raça, e por causa dela, é de sua raça, antes de tudo, que lhe cumpre tomar consciência. $^{23}$

Mas, na medida em que a negritude se esgota na tarefa de despertar uma consciência racial, ou seja, na preocupação de responder estritamente às contradições raciais, fazendo o negro reconhecer-se e identificar-se simplesmente pela cor da pele, deixa-o alienado das

\footnotetext{
${ }^{22}$ Munanga, K. Negritude..., op. cit., p. 52.

${ }^{23}$ Sartre, J. P. Reflexões sobre..., op. cit., p. 94.

Mediações - Revista de Ciências Sociais, Londrina, v. 10, n.1, p. 25-40, jan.-jun. 2005 MOVIMENTO DA NEGRITUDE: UMA BREVE RECONSTRUÇÃO HISTÓRICA Petrônio Domingues
} 
demais contradições que se operam na sociedade: exploração de classe, machismo, homofobia, etc. Assim, a negritude tem um conteúdo mais subversivo quando a afirmação dos valores negros não exclui o combate ideológico pela construção de uma sociedade mais justa e igualitária em todas as esferas da vida. A consciência negra pode estar no bojo da luta contra todas as formas de opressão. Em outras palavras, a identidade negra pode estar combinada com a reivindicação das outras dimensões da identidade, como a nacionalidade, a sexualidade, a classe social; afinal ser negro não anula as outras construções identitárias, como ser brasileiro, mulher, gay, operário ou trabalhador rural.

\section{Negritude no Brasil}

Luís Gama (1830-1882), líder abolicionista, advogado e poeta negro é considerado o precursor da ideologia da negritude no Brasil. Sua postura ideológica e produção poética, materializada na coletânea Primeiras Trovas Burlescas (cuja primeira edição é de 1859) inauguraria o discurso de afirmação racial no país. No entanto, as idéias do movimento francês da negritude somente chegaram ao Brasil na década de 1940, por meio, sobretudo do Teatro Experimental do Negro (TEN), entidade fundada em 1944 no Rio de Janeiro, e voltada inicialmente para desenvolver uma dramaturgia negra no país. Na medida em que foi adquirindo projeção, o TEN adquiriu um caráter mais amplo e passou a atuar em diversas áreas, sempre tendo em vista a afirmação dos valores negros.

Quando o grupo surgiu, a negritude passou a ser a ideologia mais geral, que imprimiu um sentido para o pensamento e as ações dos ativistas. Para o TEN, mais do que um sistema de idéias, negritude era uma filosofia de vida, uma bandeira de luta de forte conteúdo emocional e mítico, capaz de mobilizar o negro brasileiro no combate ao racismo, redimi-lo do seu complexo de inferioridade e, por conseguinte, fornecer as bases teóricas e políticas da plena emancipação. Como assevera Abdias do Nascimento, um dos fundadores do TEN:

A Negritude, em sua fase moderna mais conhecida, é liderada por Aimé Cesaire e Leopoldo Sedar Senghor, mas tem seus antecedentes seculares como Chico-Rei, Toussaint L’Ouverture, Luís Gama, José do Patrocínio, Cruz e Souza, Lima Barreto, Yomo Deniata, Lumumba, Sekou Touré, Nkrumah e muitos outros. Trata-se da assunção do negro ao seu 
protagonismo histórico, uma ótica e uma sensibilidade conforme uma situação existencial, e cujas raízes mergulham no chão histórico-cultural. Raízes emergentes da própria condição de raça espoliada. Os valores da Negritude serão assim eternos, perenes, ou permanentes, na medida em que for eterna, perene ou permanente a raça humana e seus subprodutos histórico-culturais. $^{24}$

Tal como na versão francesa, a negritude foi um ideário que floresceu no Brasil como expressão de protesto da pequena-burguesia intelectual negra (artistas, poetas, escritores, acadêmicos, profissionais liberais) à supremacia branca. Tratou-se de uma resposta dos negros brasileiros em ascensão social ao processo de assimilação da ideologia do branqueamento. Para Guerreiro Ramos, a negritude permitiu libertá-los "do medo e da vergonha de proclamar sua condição racial". ${ }^{25}$ Os postulados da negritude representaram um divisor de águas no movimento negro brasileiro na medida em que consolidaram a luta pela afirmação (ou orgulho) racial.

Entretanto, os intelectuais negros que conclamavam a negritude no Brasil jamais teriam dado uma formulação explícita e sistemática ao conceito, isto é, em nenhum instante transformaram a idéia vaga e difusa de negritude em propostas concretas ou, em última instância, traduziram a negritude em um projeto mais geral para resolver o problema do negro brasileiro. Nas palavras de Clóvis Moura,

[...] o que esse grupo [TEN] apresentava à grande comunidade negra marginalizada nas favelas, nas fazendas de cacau e de algodão, nas usinas de açúcar, nos alagados e nos pardieiros das grandes cidades? Nada.

Isto levou a que a negritude dessa fase, apesar dos protestos de grupos negros isolados, como o de Solano Trindade que lutou até a morte para dar uma conotação popular e revolucionária à negritude, o certo é que a sua aristocratização e intelectualização se desenvolveram de modo inequívoco. O grupo do Teatro Experimental do Negro [...] procurou imprimir às suas atividades um cunho de elite intelectual negra. ${ }^{26}$

\footnotetext{
${ }^{24}$ Nascimento, Abdias do. O negro revoltado. Rio de Janeiro: GRD, 1968. p. 50.

${ }^{25}$ Apud Pinto, Luís de Aguiar Costa. O negro no Rio de Janeiro: relações de raça numa sociedade em mudança. 2 $2^{\mathrm{a}}$. edição. Rio de Janeiro: Ed. UFRJ, 1998. p. 257.

${ }^{26}$ Moura, Clóvis. "Os dilemas da negritude". In: Brasil: as raízes do protesto negro. São Paulo: Global Ed., 1983. p. 103.

Mediações - Revista de Ciências Sociais, Londrina, v. 10, n.1, p. 25-40, jan.-jun. 2005 MOVIMENTO DA NEGRITUDE: UMA BREVE RECONSTRUÇÃO HISTÓRICA

Petrônio Domingues
} 
Por isso, Costa Pinto entende que ideário de negritude forjado pelo TEN não passava de um mito: "o processo é o mesmo da formação de todo mito; retira-se dos fatos uma abstração, considera-se essa abstração como um fato, e passa-se a enxergar, a pensar, a sentir, a agir em função dessa concepção invertida e mistificada das coisas". ${ }^{27}$

De acordo com aquele ideário, o negro possuiria atributos específicos, dentre os quais uma sensibilidade aguçada, que o deixava predestinado ao drama, à música, à poesia, à literatura, à dança, ao canto, enfim, às artes. Cumpre assinalar, todavia, que a contribuição sentimental e a predisposição para as artes não são traços específicos da "raça" negra no Brasil, mas resultado histórico de seu processo de adaptação sócio-cultural ao país. Nessa perspectiva, a emotividade inata do negro e sua propensão para o lúdico não passam de um perigoso mito, pois alimenta o preconceito corrente de considerar todos os indivíduos desse grupo racial como incapazes de desenvolver seu potencial para as atividades que exigem racionalidade, seriedade e habilidade intelectual. Como adverte Costa Pinto:

[...] a mesma falsa interpretação do problema que leva os negros entusiasmados com a idéia da negritude a exalçar um extraordinário pendor musical que enxergam na raça - esse mesmo pendor, igual e falsamente interpretado nos mesmos termos da tese da negritude como traço intrínseco à raça e "paideumático" - é apontada pelos estereótipos da sociedade branca como prova de que o 'negro não dá mesmo para outra coisa', 'negro só está contente com chicote no lombo, cachaça no buxo e viola na mão ${ }^{28}$

De toda sorte, o conceito de negritude popularizou-se no país com o tempo, ampliando seu raio de inserção social e adquirindo novos significados. A partir do final da década de 1970, negritude tornou-se sinônimo do processo mais amplo de tomada de consciência racial do negro brasileiro. No terreno cultural, a negritude se expressava pela valorização dos símbolos culturais de origem negra, destacando-se o samba, a capoeira, os grupos de afoxé. No plano religioso, negritude significava assumir as religiões de matriz africana, sobretudo o candomblé. Na esfera política, negritude se definia pelo engajamento na luta anti-racista, organizada pelas centenas de entidades do movimento negro.

\footnotetext{
${ }^{27}$ Pinto, L. A. C. O negro no Rio de Janeiro..., op. cit., p. 256.

${ }^{28}$ Idem, ibidem, p. 258.

Mediações - Revista de Ciências Sociais, Londrina, v. 10, n.1, p. 25-40, jan.-jun. 2005 MOVIMENTO DA NEGRITUDE: UMA BREVE RECONSTRUÇÃO HISTÓRICA Petrônio Domingues
} 
Contemporaneamente, a ideologia da negritude é tão elástica que ainda podemos identificar sua expressão em diversas outras manifestações lúdicas e estéticas de afirmação racial: nos bailes da comunidade negra, nos grupos de dança e música afro, na proposta de alguns escritores e poetas que produzem literatura negra. Ela foi inclusive, apropriada pela indústria cultural e transformada em produto de consumo. Casos típicos dessa tendência é o verdadeiro comércio que se instaurou das roupas que têm o padrão estético africano e os cosméticos dirigidos para o segmento negro. Por isso, Diva Damato salienta que, em função da ambigüidade e imprecisão, a palavra "negritude" passou a ser manipulada conforme a conveniência de cada contexto. ${ }^{29}$

\section{Considerações finais}

A ideologia da negritude foi antes de tudo, um movimento de resgate da humanidade do negro, o qual se insurgiu contra o racismo imposto pelo branco no contexto da opressão colonial. O movimento tinha a proposta de repudiar os valores estéticos da civilização ocidental. Havia uma tendência dos povos negros colonizados na África e nas Antilhas de assimilar o padrão cultural europeu, alienando-se dos valores da cultura africana. $\mathrm{O}$ fenômeno da assimilação foi denunciado, metaforicamente por Franz Fanon no título de seu livro Pele negra, máscaras brancas, uma alusão aos negros que - para integrar-se socialmente - auto-rejeitavam-se, incorporando em seus "corpos e mentes" o ideal de ser branco, alisando o cabelo e assumindo deste último a música, a religião, os costumes, em suma, a cultura. Foi justamente para reagir a esse estado de alienação que surgiu o movimento da negritude, que trazia em seu bojo o desejo de reencontro com uma identidade presumivelmente perdida. Como a libertação do negro passa pela reconquista de si, o movimento da negritude assumirá a cor negada e verá nela traços de beleza. Poetas, romancistas, etnólogos, filósofos e historiadores restituíram à África o orgulho de seu passado, demostraram o valor de sua cultura, recusaram uma assimilação que teria

\footnotetext{
${ }^{29}$ Damato, D. Negritude..., op. cit., p. 112. Além da bibliografia sobre a negritude indicada no decorrer do artigo, ver também Alves, Henrique L. Negritude. São Paulo: s/ed., 1966; Appiah, Dwame Anthony. Na casa de meu pai. Trad. Vera Ribeiro. Rio de Janeiro: Contraponto, 1997; Bastide, Roger. "O novo conceito de negritude". Cadernos Brasileiros, vol. 4, n 4, Rio de Janeiro, 1962, pp. 105-109; Benot, Yves. Ideologia das independências africanas. Vol. 1. Lisboa: Ed. Sá da Costa, 1981; Neves, Fernando. Negritude, Independência, Revolução. Paris: Edições Etc, 1975.
} 
emasculado seu protagonismo. Na medida em que foi se ampliando, a proposta de recuperação da personalidade negra serviu de modelo de atuação nas esferas política, econômica e social.

A negritude também teria se forjado da compreensão de que a cor da pele é mais do que um "acidente" genético. Ela expressaria uma ética, estética, uma forma e uma substância específicas, inalienáveis da civilização negra e de sua cosmovisão (o sentimento de coletivismo, o ritmo, a concepção sexual, a comunicação com a natureza, o culto dos antepassados). Uma forma de ser e estar no mundo que "um branco não poderá jamais entender, porque não possui a experiência interior dela". ${ }^{30}$ Porém, é necessário tomar cuidado com essa visão mítica ou essencialista; afinal, não existe negritude de maneira transcendental ou trans-histórica. Com a libertação do jugo colonial, muitos antilhanos e norte-americanos negros, "vão à África e sentem-se estrangeiros. Ao desencanto segue-se uma consciência mais ou menos vaga e imprecisa de que a 'alma negra universal talvez seja muito mais uma produção literária do que uma realidade existencial". Nesse sentido, a ideologia da negritude tinha um componente de romantismo, que levou a "fazer da África tradicional um símbolo utópico de inocência e pureza". ${ }^{31}$

Como foi dito alhures, negritude foi fundamentalmente um movimento literário nos seus primórdios, fruto de um sentimento de frustração dos intelectuais africanos e antilhanos de língua francesa, por não se sentirem representados pela cultura ocidental de matriz eurocêntrica. Tratou-se de um protesto contra a atitude do branco de desprezar a originalidade da cultura negra, um ato de recusa à assimilação colonial, enfim, uma defesa dos valores raciais do mundo negro. Significou, igualmente, uma libertação subjetiva: o negro deixou de sentir-se inferior e passou a ter orgulho de si mesmo. Foi em função da ideologia da negritude que o movimento negro brasileiro passou a encampar os valores da cultura e estética negra, assim como realizou um trabalho mais sistemático de reforço da auto-estima dos afro-descendentes.

É comum a defesa da fraternidade universal e da irmandade entre todos os homens, sempre tendo em vista o fim das categorias raciais, regionais, nacionais e de classe. Essa tendência caracterizada de discurso universalista ${ }^{32}$ é um engodo, porque não se atinge o

\footnotetext{
${ }^{30}$ Sartre, J. P. Reflexões sobre..., op. cit.

${ }^{31}$ Damato, D. Negritude..., op. cit., p. 126.

${ }^{32}$ Munanga, K. Negritude..., op. cit.. 
plano universal sem passar pelo que é específico e particular. O universalismo se constrói como soma e não como síntese ou anulação das identidades específicas de raça, classe ou nação. Portanto, qualquer universalismo abstrato em última instância, só serve para ocultar as diferenças e transformar o "outro" em ser invisível. Além disso, ao negro não "há escapatória, nem subterfúgios, nem 'passagem de linha` a que possa recorrer; um judeu, branco entre os brancos, pode negar que seja judeu, declarar-se homem entre homens. $\mathrm{O}$ negro não pode negar que seja negro ou reclamar para si esta abstrata humanidade incolor: ele é preto. Está pois encurralado na autenticidade: insultado, avassalado". ${ }^{33}$

Em dezembro de 1947, simultaneamente em Dacar e Paris, publicou-se o primeiro número da revista Présence Africaine, fundada por Alioune Diop. Esta revista tornou-se uma espécie de órgão oficial dos continuadores do movimento da negritude. Sua finalidade era definir a originalidade africana e apressar sua inserção no mundo moderno, porém, como atesta Diva Damato "essa originalidade se limitará ao cultural". ${ }^{34}$ Com efeito, Présence Africaine constituiu-se uma referência básica para se conhecer a trajetória posterior do movimento da negritude.

No cômputo geral podemos verificar alguns ganhos advindos do movimento da negritude, dentre os quais são dignos de nota: permitiu a revalorização da herança ancestral africana; contribuiu para o negro construir uma auto-imagem positiva; propiciou visibilidade e o conseqüente fim do silêncio que pairava diante da causa negra. Já os pontos negativos não foram desprezíveis, a saber: ter legitimado o preconceito secular de considerar que a dependência do negro-africano à racionalidade eurocêntrica deriva da sua intrínseca emotividade; haver educado o negro a levar a cabo uma prática revolucionária estritamente no campo racial, sem a preocupação de esposar a luta emancipatória nas demais esferas da vida (social, política e de gênero, por exemplo) e, por último, o movimento da negritude foi incapaz de romper com a lógica da dominação imposta pelos países do centro aos da periferia, sobretudo aos africanos, os quais após o jugo colonial permaneceram subordinados aos interesses do imperialismo. ${ }^{35}$

\footnotetext{
${ }^{33}$ Sartre, J. P. Reflexões sobre..., op. cit., p. 94.

${ }^{34}$ Damato, D. Negritude..., op. cit., p. 127.

${ }^{35}$ Bernd, Z. O que é negritude, op. cit., p. 41. 